\title{
To Determine the Role of Co-Enzyme Q10 and Trace Elements in Patient with Pre-Eclampsia - A Cross Sectional Study in Hyderabad
}

\author{
Farheen Shaikh, Tazeen Shah, Shafaq Ansari, Sanum Dahri
}

ABSTRACT

OBJECTIVE: The pre-eclampsia is most common hypertensive and life threatening disorder during pregnancy. Abnormal placenta may be involved in the pathogenesis of pre-eclampsia. Co-Enzyme Q10 and trace elements has been proposed as novel factors concerned in development of pre-eclampsia.

STUDY DESIGN: Cross sectional, comparative study

SETTING: Study was conducted in Biochemistry department Liaquat University of Medical \& Health Sciences Jamshoro and patients were recruited from department of Obstetrics \& Gynecology Liaquat University Hospital Jamshoro / Hyderabad

DURATION: $1^{\text {st }}$ February 2015 to $30^{\text {th }}$ October 2015.

METHODS: Total 210 volunteers were recruited, from which $\mathbf{5 0}$ volunteers were normotensive healthy pregnant women as a control and $\mathbf{1 6 0}$ were pre-eclamptic patients as cases. The subjects were recruited based on sign and symptoms, taking obstetric history, anthropometric, clinical data and collecting blood sample from volunteers. The CoQ10 was evaluated on HPLC while zinc, copper and magnesium on Atomic Absorption Spectrophotometer.

RESULTS: The plasma Co-Enzyme Q10 levelwere found decreased in pre-eclamptic patients (mean $\pm S$.D) $(0.22 \pm 0.09) \mu \mathrm{g} / \mathrm{dl}$ as compared with control group $(1.08 \pm 0.37) \mu \mathrm{g} / \mathrm{dl}$ with significant difference of $p<0.05$. Serum zinc, copper and magnesiumlevels in pre-eclampsia were decreased significanlty, it was noted as $(2.94 \pm 0.44), \mathrm{Cu}^{++}(0.19 \pm 0.09)$ and $\mathrm{Mg}^{++}(1.16 \pm 0.08) \mathrm{mg} / \mathrm{dl}$ as compared with normotensive women $(5.09 \pm 0.29),(0.36 \pm 0.03)$ and $(2.15 \pm 0.09) \mathrm{mg} / \mathrm{dl}$ with significant difference of $p<0.05$ respectively.

CONCLUSION: The observation showed that the CoQ10 and trace elements are essential for the healthy pregnancy, declined concentration of CoQ10 and essential trace elements may put forward the possible involvement in the pathology of pre-eclampsia.

KEY WORDS: Pre-eclampsia, Co-Enzyme Q10, Magnesium, Copper, Zinc, High liquid chromatography, Atomic Absorption Spectrophotometer.

This article may be cited as: Shaikh F, Shah T, Ansari S, Dahri S. To Determine the Role of Co-Enzyme Q10 and Trace Elements in Patient with Pre-Eclampsia - A Cross Sectional Study in Hyderabad. J Liaquat Uni Med Health Sci. 2017;16(02):86-92. doi: $10.22442 /$ jlumhs. 171620512

\section{INTRODUCTION}

Pre-eclampsia (PE) is a pregnancy related complication characterized by development of hypertension, proteinuria after $20^{\text {th }}$ week of pregnancy with previously normal blood pressure..$^{11}$ It occurs during second or third trimester of pregnancy which is characterized by systolic blood pressure (B.P) $140 \mathrm{mmHg}$ and diastolic B.P $90 \mathrm{mmHg}$ or more, taking two readings six hourly apart in addition to protein in the urine 300 $\mathrm{mg}$ or more in 24 hours urine collection ${ }^{1,9}$.

According to several studies abnormal placenta may be responsible for development of pre-eclampsia. During normal development of placenta, cytotrophoblast invades maternal spiral arteries and convert the small size vessels to large resistance vessels. During this process the cytotrophoblast differentiate from epithelial to an endothelial phenotype and development of pseudovasculogenesis, which may triggers the symptoms of pre-eclampsia ${ }^{13}$. Placenta produces many angiogenic factors such as placental growth factor $(\mathrm{PGH})$ and vascular endothelial growth factor (VEGF). VEGF helps in promoting angiogenesis, which is necessary for synthesis of nitric oxide (NO) from endothelium, but the anti-angiogenic factors restrict the above activities and prompt endothelial dysfunction, hypertension and proteinuria ${ }^{18}$.

Co-Enzyme Q10 (CoQ10) also known as Ubiquinone ${ }^{1}$. CoQ10 is naturally present in the body, produced by the union of benzoquinone ring fused with the isoprenoid chain of various lengths. It is synthesized by mevalonate pathway ${ }^{14}$. It is essential component of mitochondria and plays an important role in the synthesis of ATP and exhibits both antioxidant and membrane stabilizing property ${ }^{8,15}$. CoQ10 participate in electrons transport inside the mitochondria of the 
cell thus either hydrogen ions and electrons are gained or lost by CoQ10 ${ }^{7}$. It also helps to regenerate oxidized vitamin $\mathrm{E}$ to strong antioxidant ${ }^{5}$. The normal concentration of plasma CoQ10 is 0.4 to $1.9 \mu \mathrm{g} / \mathrm{ml}^{8}$. The antioxidant or free radical quenching properties of CoQ10 serve to greatly reduce oxidative damage to tissues as well as significantly inhibit the oxidation of LDL cholesterol and help in decreases blood pressure in pre-eclampsia ${ }^{20}$. During pregnancy, nutritional demand is increased to fulfill the need of growing fetus.

Trace elements are involved in various biochemical pathways. Their specific and the most important functions are catalytic role in chemical reactions ${ }^{10}$.

Zinc $\left(\mathrm{Zn}^{++}\right)$is an important trace element involved in a diversity of biochemical functions in the body ${ }^{22}$. It acts as co-factor for synthesis of enzymes, DNA and RNA. Decreased concentration of $\mathrm{Zn}$ has been associated with growth retardation, congenital abnormalities, pre-eclampsia and other complications of pregnancy ${ }^{9}$. Copper $\left(\mathrm{Cu}^{++}\right)$is also vital trace element, which is important part of copper dependent enzyme such as lysyl oxidases, tyrosi-nase, dopamine- $\beta$-hydroxylase etc. Copper also containing zinc superoxide dismutase act as antioxidants and help in prevention of free radicals ${ }^{6}$.

Magnesium $\left(\mathrm{Mg}^{++}\right)$is one of the essential intracellular cation and an important co-factor for activation of many enzymes. ${ }^{4} \mathrm{Mg}^{++}$plays an important role in glucose metabolism, protein synthesis energy requiring metabolic processes, neuromuscular excitability, nervous tissue transmission, secretions of hormone, muscle contraction ${ }^{22}$. Pre-eclampsia in developing countries occurs due to inadequate dietary intake which is not rich enough in essential minerals like $\mathrm{Mg}^{++}$and $\mathrm{Zn}^{++}$, as well as vitamins, so insufficient dietary intake is harmful for mother and new born. Thus as a part of powerful antioxidant helps to protect the cell from damage ${ }^{17}$.

Aim of this study is to analyze the imbalance levels of CoQ10 and $\mathrm{Zn}^{++}, \mathrm{Cu}^{++}$and $\mathrm{Mg}^{++}$in pre-eclampsia which may put forward the possible involvement in the etiology of this life threatening disease.

\section{PURPOSE OF STUDY}

This study had conducted to compare the plasma levels of CoQ10 and $\mathrm{Zn}^{++}, \mathrm{Cu}^{++}$and $\mathrm{Mg}^{++}$in healthy pregnant women with patients with pre-eclampsia, thus present study may be helpful to early diagnosis to pre-eclampsia.

\section{OBJECTIVE OF STUDY}

- To estimate the plasma levels CoQ10, $\mathrm{Zn}^{++}, \mathrm{Cu}^{++}$ and $\mathrm{Mg}^{++}$in healthy pregnant women.

- To compare the plasma levels of CoQ10, $\mathrm{Zn}^{++}$, $\mathrm{Cu}^{++}$and $\mathrm{Mg}^{++}$in patient with pre-eclampsia.

\section{SETTING}

The study was conducted in Biochemistry
Department, Liaquat University of Medical \& Health Sciences, Jamshoro and patients were recruited from Department of Obstetrics \& Gynecology, Liaquat University Hospital Jamshoro / Hyderabad during the period of $1^{\text {st }}$ February 2015 to $30^{\text {th }}$ October 2015.

\section{SAMPLE SIZE}

The sample size calculation was done according to general calculation formula. Pre-eclampsia was $5 \%$ by using the proportion of $95 \%$ confidence interval with $5 \%$ margin of error, the sample size was stand to be $\mathrm{n}=80$. Total 210 subjects were recruited and divided into two groups. Group A: $n=50$ Healthy pregnant women with normal B.P after $20^{\text {th }}$ week of gestation and Group B: $n=160$ patient with Pre-eclampsia after $20^{\text {th }}$ week of gestation

STUDY DESIGN: Cross-sectional, Comparative study INCLUSION CRITERIA: Healthy pregnant women after $20^{\text {th }}$ week of gestation within 20-30 years of age and pregnant women with pre-eclampsia after $20^{\text {th }}$ week of gestation.

EXCLUSION CRITERIA: Pregnant women below 20 or above 35 years, multiple Pregnancy, known hypertensive, diabetic, cardiac and renal, liver disease, smokers and any use of drug.

\section{SAMPLING TECHNIQUE: Purposive Consecutive}

\section{METHOD}

The study comprised on two phases. Phase 1 was recruitment of volunteers and phase 2 was collecting blood sample from the volunteers. Population informed for the recruitment by the flyers at Department of Obstetrics and Gynecology, Jamshoro / Hyderabad.

\section{BLOOD PARAMETERS}

$5 \mathrm{ml}$ of Blood was collected from each participant by venopuncture into vacationers under aseptic measures. $3 \mathrm{ml}$ of blood was collected into EDTA test tube for CoQ10, while $2 \mathrm{ml}$ of blood into Gel test tubes for the trace elements. The blood was centrifuged at $3500 \mathrm{rpm}$ for $10 \mathrm{~min}$, fractionated and transferred to eppendorf cups then stored at $-20^{\circ} \mathrm{C}$ till required for analysis. Before the analysis, sample was first allowed to attain room temperature then used.

\section{ETHICAL CONSIDERATION}

The study was conducted strictly under the ethical rules after the approval from Ethical Review Committee of LUMHS Jamshoro. Written consent was taken from all participants and they were explained about study rationale.

\section{STATICIAL ANALYSIS PROCEDURE}

Data was entered in Microsoft Excel and analyzed on SPSS (Statistical package for Social Sciences) Version 16. Student t-test for comparison between case and control were used for continuous variable. Results were presented as mean and standard deviation. 


\section{ESTIMATION OF COQ10}

Determination of plasma CoQ10 was performed on HPLC-UV (HITACHI L-2000) by Fabrizio Mosca method ${ }^{8}$. Total CoQ10 successfully separated by column C18 Hyper Ci H Gold. Plasma CoQ10 was eluted with isocratic mobile phase methanol and ethanol with $35: 65 \mathrm{v} / \mathrm{v}$ at flow rate of $1 \mathrm{ml} / \mathrm{min}$.

\section{CHEMICALS AND REAGENTS FOR COQ10}

Methanol, Ethanol, 2-Porpanol, 1, 4- Benzoquinone and Co-enzyme Q10 as standard Chemicals were analytical grade procured from Sigma-Aldrich.

\begin{tabular}{|c|c|}
\hline Solvent system A & Solvent system B \\
\hline $\begin{array}{l}\text { Methanol and Ethanol } \\
\text { with } 35: 65 \mathrm{v} / \mathrm{v}\end{array}$ & $\begin{array}{l}\text { Methanol and distilled } \\
\text { water With 1:1 }\end{array}$ \\
\hline
\end{tabular}

\section{CHROMATOGRAPHIC CONDITIONS}

Analysis of CoQ10 was performed on HPLC-UV (HITACHI L-2000).

Solvent $-A$ system for the separation and Solvent-B for HPLC. $1 \mathrm{ml} / \mathrm{min}$ flow rate was adjusted throughout the analysis.

\section{STANDARD SOLUTION OF COQ10}

$10 \mathrm{mg}$ of CoQ10 standard mixed with $20 \mathrm{ml}$ of 2propanol in brown Erlenmeyer flask, make it $500 \mathrm{mg} /$ $\mathrm{ml}$. This stock solution was stored for one month at $4^{\circ} \mathrm{C}$. From this solution, different concentrations were prepared for standard calibration ranging from 200 ppm (Parts-per-million) to $1.3 \mathrm{ppm}$ as shown in Chromatogram 1.

\section{SAMPLE PREPARATION}

Prepare the $2 \mathrm{mg}$ of 1, 4-benzoquinone solution in 10 $\mathrm{ml}$ of distilled water. Take $50 \mu \mathrm{l}$ of 1, 4- benzoquinone and $200 \mu \mathrm{l}$ of plasma in capped test tube then vertex for 10 minutes then $1 \mathrm{ml}$ of 2-propanol was added, one more time vertex for 10 second and then centrifuge for 2 minutes at $10,000 \mathrm{rpm}$. 200 $\mu \mathrm{l}$ of supernatant injected into HPLC. Mobile phase consists on Methanol-Ethanol of $35: 65 \%$, at $1 \mathrm{ml} / \mathrm{min}$ flow rate and UV detection at the wave length of 274 $\mathrm{nm}$. In conclusion result, had been obtained as shown in chromatogram 2. Estimation of trace elements: Analytical Procedure: Trace traces like serum $\mathrm{Zn}^{++}$, $\mathrm{Cu}^{++}$and $\mathrm{Mg}^{++}$analyzed by Atomic Absorption Spectrophotometer (Varian Spectra A- 20) according to described method by Al- Jameil $\mathrm{N}^{2}$ and Mastin MT

${ }^{16}$. To analyze the trace elements from sample by aspirated the flame from beam of light, after few steps then to measured light of absorbance of compounds by its own definite wave length 213.9, 225.0 and $273.5 \mathrm{~nm}$ for $\mathrm{Zn}^{++}, \mathrm{Cu}^{++}$and $\mathrm{Mg}^{++}$respectively.

\section{RESULTS}

The results of present study were expressed as (Mean \pm S.D) are summarized in Tables 1 and 2 represented in graphs 1 and 2. Student t-test was used to calculate the level of significance. The mother age of control groups were noted as $(26.96 \pm 4.18)$ years and cases group were $(26.4 \pm 5.16)$ years respectively, while the mean difference was insignificant $p>0.61$. Mean of gestational age of control were28.76 \pm 4.47 months and cases subjects were $(27.96 \pm 4.19)$ months with insignificant difference of $p>0.7$. Systolic blood pressure of controls had been noted as $113.2 \pm 9.13$ $\mathrm{mmHg}$ while in pre-eclamptic group it was $175.9 \pm$ $34.05 \mathrm{mmHg}$. Diastolic blood pressure of control group was noted as $74.40 \pm 6.75 \mathrm{mmHg}$ and pre-eclamptic group was $99.75 \pm 8.96 \mathrm{mmHg}$ with highly significant difference $p<0.01$ as shown in table and graph 1 respectively. The mean \pm S.D of plasma Coenzyme Q10 levels in controls were noted as (1.08 $\pm 0.37) \mu \mathrm{g} / \mathrm{dl}$ and in pre-eclamptic subjects were $(0.22$ $\pm 0.09) \mu \mathrm{g} / \mathrm{dl}(\mathrm{p}<0.05)$. The plasma CoQ10 level significantly decreased in patient with pre-eclampsia as shown in table 2 and represented in graph 2 respectively.

The concentration of serum trace elements also observed as declined in cases group as compare to control group. The mean \pm S.D of serum $\mathrm{Zn}^{++}$levels in normotensive women were noted as (5.09 \pm 0.29$)$ $\mathrm{mg} / \mathrm{dl}$ as compared to pre-eclamptic women having $2.94 \pm 0.44 \mathrm{mg} / \mathrm{dl}$. The serum $\mathrm{Cu}^{++}$levels in control group had noted as $0.36 \pm 0.03 \mathrm{mg} / \mathrm{dl}$ as compared to pre-eclamptic women having $0.19 \pm 0.09 \mathrm{mg} / \mathrm{dl}$. The serum $\mathrm{Mg}^{++}$levels of normal healthy pregnant ladies were noted as $2.15 \pm 0.09 \mathrm{mg} / \mathrm{dl}$ as compared to pre-eclamptic women having $1.16 \pm 0.08 \mathrm{mg} / \mathrm{dl}$ and the mean difference was $p<0.05$ which is highly significant as shown in table 2 and represented in graph 2 respectively.

\section{Chromatogram No.1: A CoQ10 standard} calibration ranges from $200 \mathrm{ppm}$ to $1.3 \mathrm{ppm}$

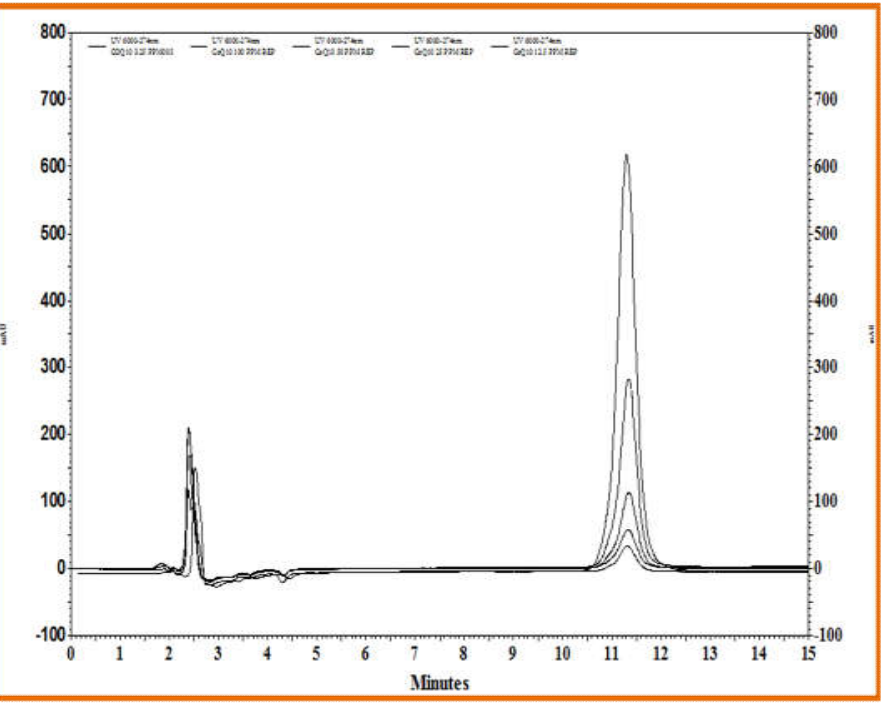


Chromatogram No. 2:

CoQ10 in patient with pre-eclampsia

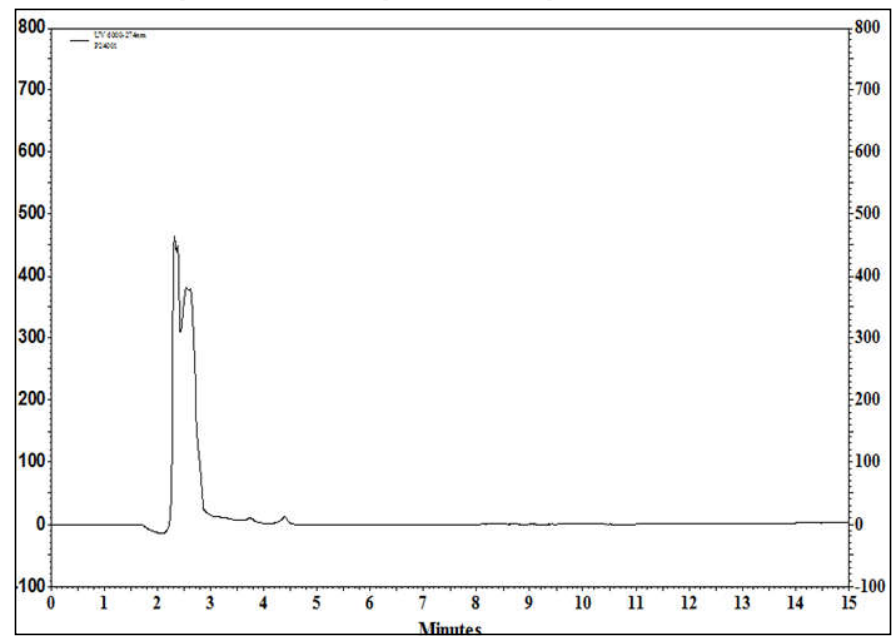

TABLE I: COMPARISON OF AGE, GESTATIONAL AGE, SYSTOLIC AND DIASTOLIC BLOOD PRESSURE BETWEEN CONTROL AND CASES GROUPS

\begin{tabular}{|l|c|c|c|}
\hline \multirow{2}{*}{ Variables } & Control & Cases & \multirow{2}{*}{ p-value } \\
\cline { 2 - 4 } & Mean \pm SD & Mean \pm SD & \\
\hline Age (years) & $26.96 \pm 4.18$ & $26.4 \pm 5.16$ & $>0.61^{*}$ \\
\hline $\begin{array}{l}\text { Gestational } \\
\text { Age (Months) }\end{array}$ & $28.76 \pm 4.47$ & $27.96 \pm 4.19$ & $>0.7^{*}$ \\
\hline $\begin{array}{l}\text { Systolic B.P } \\
\text { (mmHg) }\end{array}$ & $113.2 \pm 9.13$ & $175.9 \pm 34.05$ & $<0.01^{*}$ \\
\hline $\begin{array}{l}\text { Diastolic B.P } \\
\text { (mmHg) }\end{array}$ & $74.40 \pm 6.75$ & $99.75 \pm 8.96$ & $<0.01^{*}$ \\
\hline
\end{tabular}

The values are expressed as mean \pm standard deviation and units are given in parenthesis. Results are presented as a $p$ values and calculated by student t-test, $p$ - values are ${ }^{*} p \leq 0.05,{ }^{* *} p \leq 0.01$ as compared to control

TABLE II: COMPARISON OF RESULTS OF THIS STUDY BETWEEN COQ10, ZINC, COPPER AND MAGNESIUM IN PATIENT WITH PRE-ECLAMPSIA WITH NORMOTENSIVE HEALTHY PREGNANT WOMEN

\begin{tabular}{|l|c|c|c|}
\hline \multirow{2}{*}{ Variables } & Control & Cases & \multirow{2}{*}{ p-value } \\
\cline { 2 - 4 } & Mean \pm SD & Mean \pm SD & \\
\hline CoQ10 $(\mu \mathrm{g} / \mathrm{ml})$ & $1.08 \pm 0.37$ & $0.22 \pm 0.09$ & $\leq 0.05^{\star}$ \\
\hline Zinc $(\mathrm{mg} / \mathrm{dl})$ & $5.09 \pm 0.29$ & $2.94 \pm 0.44$ & $\leq 0.05^{*}$ \\
\hline Copper $(\mathrm{mg} / \mathrm{dl})$ & $0.36 \pm 0.03$ & $0.19 \pm 0.09$ & $\leq 0.05^{\star}$ \\
\hline $\begin{array}{l}\text { Magnesium } \\
(\mathrm{mg} / \mathrm{dl})\end{array}$ & $2.15 \pm 0.09$ & $1.16 \pm 0.08$ & $\leq 0.05^{\star}$ \\
\hline
\end{tabular}

The values are expressed as mean \pm standard deviation and units are given in parenthesis. Results are presented as a $p$ values and calculated by student t-test, $p$ - values are ${ }^{*} p \leq 0.05,{ }^{* *} p \leq 0.01$ as compared to control

Graph No. 1: Age of mothers (years), Gastational Age (months), systolic and diastolic B.P $(\mathrm{mmHg})$ control and cases groups. Significant difference observed when comparing with pre-eclamptic women with healthy pregnant ladies at $p<0.05$

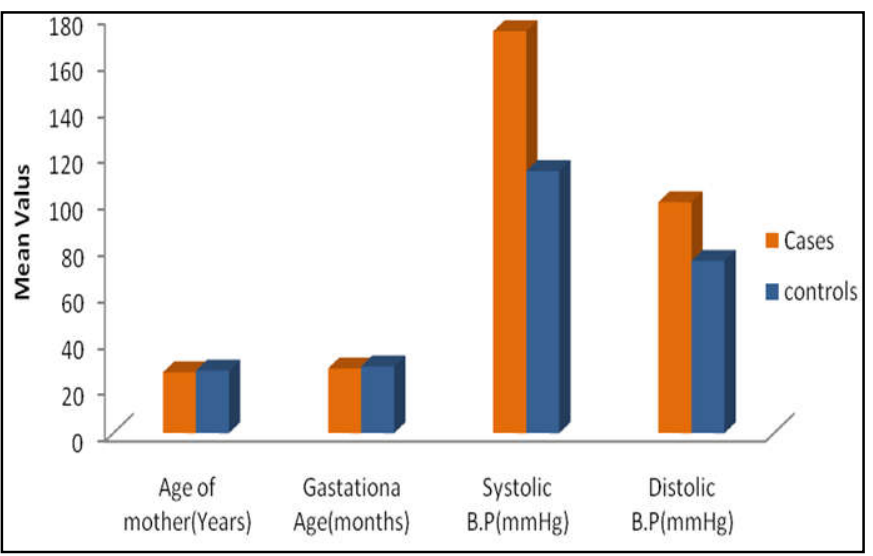

Graph No. 2: Plasma CoQ10 (ug/dl), Serum zinc, copper and magnesium $(\mathrm{ml} / \mathrm{dl})$ in control and cases groups, Significant difference observed when comparing with pre-eclamptic women with healthy pregnant ladies at $p<0.05$

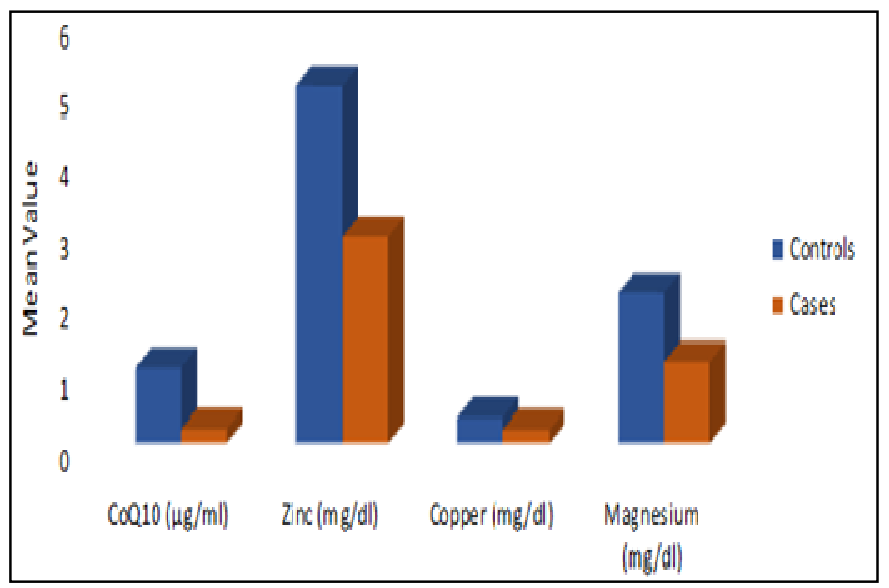

\section{DISCUSSION}

Pre-eclampsia is a multisystem life threatening disease that affects both the mother and fetus. In developing countries the incidence are increasing day by day. In pregnancy the process of implantation, proliferation and trophoblast invasion, produces reactive oxygen species but it is thought that in pre-eclampsia it is uncontrolled and balance between oxidative stress and antioxidant were disrupted ${ }^{18}$. Many studies 
had been reported by researchers on antioxidants and they thought that by analyzing the antioxidants may be helpful for early detection of variable in biomarker. The present study had been undertaken to analyze and to discriminate the early appearance of CoQ10, $\mathrm{Zn}^{++}, \mathrm{Cu}^{++}$and $\mathrm{Mg}^{++}$to early diagnosis. Pre-eclampsia is more common in pregnant women more than 20 years of age and more than 35 years. Our study observed that the maternal and gestational age of control group and cases group were mostly similar and show no any significant difference. Many researchers ${ }^{12,19}$ observed no difference in gestational age among normotensive pregnant group and pre-eclamptic group which had been conformity with our finding and well supporting my study subjects had been compared it was noted to be almost equal.

The angiogenic growth factors trigger the inflammatory response result in blood pressure and other symptoms of pre-eclampsia ${ }^{10}$. Recent literature indicates that increased in blood pressure during pregnancy is associated with various obstetrics pathologies ${ }^{23}$. English FA. et al ${ }^{7}$ reported that during pre-eclampsia glomerular filtration rate and cardiac output increases, resulting in blood pressure due to increased production of oxidants and antioxidant. Present study ruled out the influence of severity of pre -eclampsia due to systolic and diastolic blood pressure noted as normal in control group but high in pre-eclamptic group $(p<0.01)$. This confirms the earlier investigation with minor changes which may be due to ethnic difference.

The CoQ10 performed very important part in electron transport chain and help in generating energy in form of ATP. According to Teran E et al ${ }^{20}$ CoQ10 is an important antioxidant, produced by all cell and required for primary action of cells by producing electrons and molecular oxygen. It prevents the oxidative stress in all cellular membranes, lipoproteins and blood serum. In present study plasma CoQ10 levels were observed to be decreased significantly in pre-eclamptic patients as compared to normotensive subjects $(p<0.05)$ Bor-Jen Lee et al ${ }^{5}$ had reported that throughout gestation the placental metabolism is maintained by mitochondrial CoQ10 which is important for embryo development. Increased consumption of CoQ10 and other antioxidant may develop the pregnancy induced hypertension. In our study it was analyzed that in pre-eclamptic women plasma CoQ10 levels were significantly decrease as compare to healthy pregnant women.

Dave $\mathrm{J}$ et al ${ }^{12}$ had revealed in her study that during oxidative stress production of free radicals and consumption of antioxidants increases, which includes vitamins, trace elements, antioxidants enzymes such as glutathione peroxidase and superoxide dismutase and CoQ10. These findings are supporting the present study that plasma CoQ10 and serum $\mathrm{Zn}^{++}$, $\mathrm{Cu}^{++}$and $\mathrm{Mg}^{++}$levels were significantly decreased in patients with pre-eclampsia as compared to healthy pregnant women.

Yue Ma et al ${ }^{21}$ study results from their meta-analysis showed that serum $\mathrm{Zn}^{++}$level in pre-eclamptic patients were significantly lower than healthy pregnant women. During pregnancy the requirement of $\mathrm{Zn}^{++}$increases as the pregnancy progresses, this might be attributed to decrease in $\mathrm{Zn}^{++}$binding capacity and also effects on estrogen levels which may lead to cause oxidative stress. This hypothesize supported our study that $\mathrm{Zn}^{++}$ declined in cases as compared to the control subjects with significant difference of $(\mathrm{P}<0.05) . \mathrm{Cu}^{++}$has been playing a key role in function of several copper containing enzymes that are essential for life. Al-Jameil N. et al ${ }^{2}$ reported that low levels of $\mathrm{Cu}++$ in pre-eclamptic women may be associated with impairment of the cell antioxidant capacity and oxidant / antioxidant balance. These findings well supported present study that decrease in the serum $\mathrm{Cu}^{++}$levels in cases group as compared to control group.

Sarwar MS et al ${ }^{19}$ have mentioned in their study $\mathrm{Cu}^{++}$ deficiency during pregnancy may causes maternal and fetal complications because many enzymes need copper for their activation and its metabolic function but its deficiency slow down or inhibit the enzymatic reaction. In present study it was observed that $\mathrm{Cu}^{++}$ level declined in pre-eclamptic patients as compared to the healthy pregnant women $(p<0.05)$. $\mathrm{Mg}^{++}$is a vital ion that plays an important role in human body ${ }^{10}$. The concentration variations can have clinical significance; to prevent any disharmony maintenance of standard values is crucial. Conditions which disturb the normal levels include pre-eclampsia, intra growth retardation etc ${ }^{22}$.

Smith JM et al ${ }^{11}$ observed that serum $\mathrm{Mg}^{++}$levels were declined in pre-eclamptic patients early screening of serum levels of $\mathrm{Mg}^{++}$will be helpful to manage the patients and protect the mother as well as her baby. In present study it was found that $\mathrm{Mg}^{++}$levels were decreased due to increased oxidative stress in pre-eclamptic women as compared to controls.

Vafaei $\mathrm{H}$ et al ${ }^{10}$ had reported that the serum $\mathrm{Mg}^{++}$ levels were not significantly different in pre-eclamptic and normotensive women. In our study the $\mathrm{Mg}^{++}$level significantly decreased in pre-eclamptic patient as compared to the controls. 


\section{CONCLUSION}

The alteration in plasma CoQ10 levels and trace elements could contribute in the pathogenesis of Pre-Eclampsia. There was a significant statistical decline in the levels of CoQ10 zinc, copper and magnesium in pre-eclamptic patients compared to control healthy pregnant women.

\section{RECOMMENDATION}

The present study recommended further studies are needed to access the probable factors for the early detection for developing pre-eclampsia; so that preventive measures can be taken earlier and other pregnant ladies coming for the antenatal care can be accessed on the glance of this study.

\section{ACKNOWLEDGMENT}

Authors would like to thanks to technical advisor of National center of excellence in Analytical Chemistry, University of Sindh, Jamshoro, who supported in all stages of study.

\section{REFRENCES}

1. Abo-Elmatty DM, Badawy EA, Hussein JS, et al. Role of heme oxygenase, leptin, coenzyme Q10 and trace elements in pre-eclamptic women. Indian J Clin Biochem 2012;27(4):379-84.

2. Al-Jameil $\mathrm{N}$, Tabassum $\mathrm{H}$, Al-Mayouf $\mathrm{H}$, et al. Analysis of serum trace elements-copper, manganese and zinc in preeclamptic pregnant women by inductively coupled plasma optical emission spectrometry: a prospective case controlled study in Riyadh, Saudi Arabia. Int J Clin Exp Pathol. 2014;7(5):1900-10.

3. Cunha AR, Umbelino B, L.Correia M, Neves MF. Magnesium and vascular changes in hypertension. IJH 2012; 1:1-7.

4. Singh A, Verma AK, Hassan G, et al. Serum magnesium levels in patients with pre-eclampsia and eclampsia with different regimens of megnesium sulphate. GJMEDPH 2013; 2(1): 1-9.

5. Bor-Jen Lee, Yi-Chin Lin, Yi-Chia Huang, et al. The relationship between coenzyme Q10, oxidative stress, and antioxidant enzymes activities and coronary artery disease. Scientific World Journal 2012; 3:1-8.

6. Farzin L, Sajadi F. Comparison of serum trace element levels in patients with or without preeclampsia. J Res Med Sci 2012; 17(10): 938-41.

7. English FA., Kenny LC, McCarthy FP. Risk factors and effective management of preeclampsia. Integr Blood Press Control 2015; 8: 7-12.
8. Mosca F, Fattorini D, Bompadre S, Littarru GP. Assay of coenzyme Q10 in plasma by a single dilution step. Analytical Biochemistry 2002; 305 (1): 49-54.

9. Al-Shalah HH, Al-Hilli NM, Hasan MA. The association of serum iron zinc and copper levels with preeclampsia. Med J Babylon. 2016; 12:4.

10. Vafaei H, Dalili M, Amin Hashemi S. Serum concentration of calcium, magnesium and zinc in normotensive versus preeclampsia pregnant women: a descriptive study in women of kerman province of Iran. Iran J Reprod Med 2015;13(1): 23-26.

11. Smith JM, Lowe RF, Fullerton J, et al. An integrative review of the side effects related to the use of magnesium sulfate for pre-eclampsia and eclampsia management. BMC pregnancy and childbirth. 2013; 13 (1): 34.

12. Dave J, Vaidya M, Verma M. A comparative study of degree of oxidative stress in pre-eclamptic \& healthy pregnant women in M.P. India. IJAPB 2012; 1(3):1-5.

13. Sanchez-Aranguren LC, Prada CE, Riano-Medina $\mathrm{CE}$, et al. Endothelial dysfunction and preeclampsia: role of oxidative stress. Front Physiol. 2014; 5:372.

14. Lin SH, Yan JY. Study of coenzyme Q10 in the liver of preeclampsia pregnant rats. Zhonghua $\mathrm{Fu}$ Chan Ke Za Zhi. 2016;51(8):608-15.

15. Littarru GP, Tiano L. Clinical aspects of coenzyme Q10: an update. Nutrition.2010; 26(3):250-4.

16. Mastin M T, Shaprio R. Atomic absorption spectrometry of magnesium methods Enzymol. 1988; 158: 365-70.

17. Sharma $P$, Chung $C$, Vizcaychipi M. Magnesium: The Neglected electrolyte? A clinical review. Pharmacology and Pharmacy 2014; 5(7): 762-72.

18. Powe CE, Levine RJ, Karumanchi SA. Preeclampsia, a disease of the maternal endothelium: the role of anti-angiogenic factors and implications for later cardiovascular disease. Circulation 2011; 123(24):2856-69.

19. Sarwar MS, Ahmed S, Ullah MS, et al. Comparative study of serum zinc, copper, manganese and iron in preeclamptic pregnant women. Biol. Trace Elem Res. 2013; 154 (1): 14-20.

20. Teran E, Hernandez I, Nieto B, et al. Coenzyme Q10 supplementation during pregnancy reduces the risk of pre-eclampsia. Int $\mathrm{J}$ Gynecol Obstet 2009; 105(1):43-5.

21. Yue Ma, Xiaoli Shen, Dongfeng Zhang. The relationship between serum zinc level and preeclampsia: A Meta-Analysis. Nutrients 2015;7(9):7806-20. 
22. Tavana Z, Hosseinmirzaei S. Comparison of maternal serum magnesium level in pre-eclampsia and normal pregnant women. Iran Red Crescent Med J. 2013; 15(12):e10394.
23. Wright D, Syngelaki A, Akolekar R, et al. Competing risks model in screening for preeclampsia by maternal characteristics and medical history. Am J obstet Gynecol 2015; 213(1):62.e1-10.

AUTHOR AFFILIATION:

Dr. Farheen Shaikh (Corresponding Author) Department of Biochemistry

Liaquat University of Medical and Health Sciences

(LUMHS), Jamshoro, Sindh-Pakistan.

Email: shaikhfarheen14@gmail.com

Dr. Tazeen Shah

Department of Physiology

LUMHS, Jamshoro, Sindh-Pakistan.

Dr. Shafaq Ansari

Department of Anesthesiology

LUMHS, Jamshoro, Sindh-Pakistan.

Dr. Sanum Dahri

Department of Anatomy

Basic Medical Sciences Institute

Jinnah Postgraduate Medical Center

Karachi, Sindh-Pakistan. 